\title{
A Distinct Array of Proinflammatory Cytokines Is Expressed in Human Colon Epithelial Cells in Response to Bacterial Invasion
}

\author{
Hyun Chae Jung, * Lars Eckmann, * Suk-Kyun Yang, * Asit Panja, ${ }^{\ddagger}$ Joshua Fierer, * Ewa Morzycka-Wroblewska, * \\ and Martin F. Kagnoff* \\ *Department of Medicine, University of California, San Diego, La Jolla, CA 92093-0623; and ${ }^{\ddagger}$ Division of Clinical Immunology, \\ Mount Sinai Medical Center, New York 10029
}

\begin{abstract}
Pathogenic bacteria that penetrate the intestinal epithelial barrier stimulate an inflammatory response in the adjacent intestinal mucosa. The present studies asked whether colon epithelial cells can provide signals that are important for the initiation and amplification of an acute mucosal inflammatory response. Infection of monolayers of human colon epithelial cell lines (T84, HT29, Caco-2) with invasive strains of bacteria (Salmonella dublin, Shigella dysenteriae, Yersinia enterocolitica, Listeria monocytogenes, enteroinvasive Escherichia coli) resulted in the coordinate expression and upregulation of a specific array of four proinflammatory cytokines, IL-8, monocyte chemotactic protein-1, GMCSF, and TNF $\alpha$, as assessed by mRNA levels and cytokine secretion. Expression of the same cytokines was upregulated after TNF $\alpha$ or IL-1 stimulation of these cells. In contrast, cytokine gene expression was not altered after infection of colon epithelial cells with noninvasive bacteria or the noninvasive protozoan parasite, $G$. lamblia. Notably, none of the cell lines expressed mRNA for IL-2, IL-4, IL-5, IL-6, IL$12 p 40$, IFN- $\gamma$, or significant levels of $I L-1$ or IL-10 in response to the identical stimuli. The coordinate expression of IL-8, MCP-1, GM-CSF and TNF $\alpha$ appears to be a general property of human colon epithelial cells since an identical array of cytokines, as well as IL-6, also was expressed by freshly isolated human colon epithelial cells. Since the cytokines expressed in response to bacterial invasion or other proinflammatory agonists have a well documented role in chemotaxis and activation of inflammatory cells, colon epithelial cells appear to be programmed to provide a set of signals for the activation of the mucosal inflammatory response in the earliest phases after microbial invasion. ( $J$. Clin. Invest. 1995. 95:55-65.) Key words: MCP-1 • IL-8 - GM-CSF - TNF $\alpha$ IL-6 - reverse transcription PCR • inflammation
\end{abstract}

H. C. Jung and L. Eckmann contributed equally to this work.

Address correspondence to Martin F. Kagnoff, M.D., Department of Medicine 0623D, University of California, San Diego, 9500 Gilman Drive, La Jolla, CA 92093-0623. Phone: 619-534-4622; FAX: 619-5345691 . H. C. Jung's present address is Seoul National University, College of Medicine, Seoul, Korea.

Received for publication 12 April 1994 and in revised form 6 September 1994.

J. Clin. Invest.

(c) The American Society for Clinical Investigation, Inc.

$0021-9738 / 95 / 01 / 0055 / 11 \quad \$ 2.00$

Volume 95, January 1995, 55-65

\section{Introduction}

Cells that line the mucosal surface of the intestine form a major mechanical barrier that separates the host's internal milieu from the external environment. In addition to the well established role of epithelial cells in ion transport, these cells appear to function as an integral component of the mucosal immune system. Thus, human colon epithelial cells in vitro can process and present antigens to T cells (1), and the human colon epithelium in vivo and in vitro can be stimulated to express HLA class II $(2,3)$ and intercellular adhesion molecules (4-6). In addition, human colon epithelial cells and cell lines produce IL-8 (7, 8 ), a potent neutrophil chemoattractant and, as assessed by immunohistochemistry, $\sim 5 \%$ of human colon epithelial cells in vivo produce IL-6 (9). Moreover, human colon epithelial cell lines express TGF $\beta 1(7,10)$, complement proteins (C3, $\mathrm{C} 4$, Factor B) (11), and leukotrienes that may be involved in the initiation and regulation of mucosal inflammatory responses (12). Colon epithelial cell lines also can respond to a broad array of cytokines (e.g., TNF $\alpha$, IL-1, IL-4, IL-6, IFN- $\gamma$, TGF $\beta 1$ ) with altered gene expression and growth characteristics (7, 13-18).

Cytokines produced by a number of different cell types play an essential role in intercellular communication by delivering signals which influence the activation, growth, differentiation, or migration of the target cells upon which they act. Individual cells can produce multiple cytokines. Moreover, populations of cells can be grouped according to the array of cytokines they produce, which in turn influences the spectrum of functions that the cell mediates. For example, human CD4 T cell clones, like those initially described in mice (19), can be divided into functionally distinct subsets depending on whether they produce the cytokines IL-2 and IFN- $\gamma$ or, alternatively, IL-4 and IL-5 (2022 ). This coordinate regulation of specific groups of cytokines has important consequences for the host response to microbial pathogens since resistance or susceptibility can correlate closely with the specific group of cytokines expressed (23-25). Cytokines also can be categorized based on their major activities. For example, the cytokines TNF $\alpha$, IL- 1 and GM-CSF, as well as IL-8, MCP-1 and other chemokine family members can activate a spectrum of proinflammatory effects, whereas cytokines such as TGF $\beta 1$ and IL-10 can mediate effects that downregulate inflammatory responses (26-28). Cytokine signaling between cells often involves a network of effects. Thus, stimulation of cells with one group of cytokines (e.g., TNF $\alpha$ or IL-1) may result in the production by those cells of other cytokines (e.g., IL-8, monocyte chemotactic protein- $[\text { [MCP-1] })^{1}$ that mediate

1. Abbreviations used in this paper: IEL, intraepithelial lymphocyte; $\mathrm{MCP}$, monocyte chemotactic protein; RT, reverse transcription. 

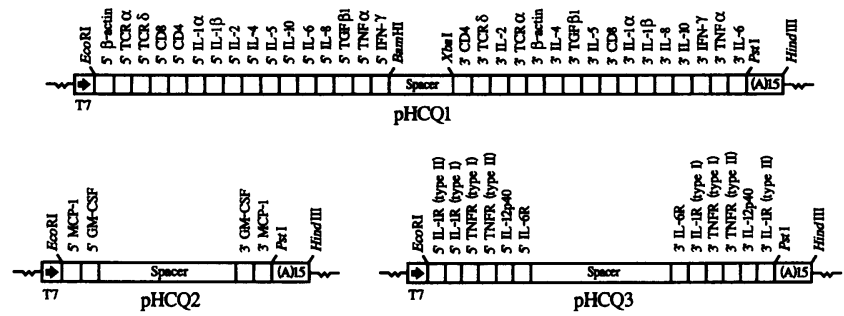

Figure 1. Structure of pHCQ plasmids used for generation of standard RNA. Plasmid $\mathrm{pHCQ} 1$ has $5^{\prime}$ and $3^{\prime}$ priming sites for 11 cytokine genes as well as $\beta$-actin, TCR $\alpha, \operatorname{TCR} \delta, \operatorname{CD} 8$, and CD4. The priming sites correspond to the sequences of the primers used to amplify target cDNA. The arrangement of priming sites was designed to yield PCR products that differ in size from those of the target RNA. Sequences are flanked upstream by a T7 RNA polymerase promoter and downstream by a poly (A) sequence. Using the same strategy, plasmids pHCQ2 and pHCQ3 were constructed to quantitate the mRNA for MCP1 and GM-CSF or IL-12p40, respectively. Plasmid pHCQ3 also encodes priming sites for IL-1 receptor type 1 and 2 , TNF $\alpha$ receptor type 1 (p55) and type 2 (p75) and the IL-6 receptor.

additional effects which serve to further amplify an inflammatory response (29).

Other than IL-8, little is known regarding the overall repertoire of cytokine genes whose expression is regulated in human colon epithelial cells in response to environmental stimuli. In the present study, we describe the coordinated and regulated expression of a specific array of proinflammatory cytokines in human colon epithelial cells in response to bacterial invasion and TNF $\alpha$ or IL-1 stimulation. Alone and in combination, these cytokines are known to attract and activate inflammatory cells and thus may provide an important early signaling system for the initiation and amplification of the mucosal inflammatory response in the early stages of bacterial infection, after penetration of the host epithelial barrier by pathogenic microbes.

\section{Methods}

RNA standards for quantitative PCR. To facilitate quantitation of cytokine RNA by PCR, we constructed three plasmids, pHCQ1, pHCQ2, and pHCQ3 (Fig. 1), which encode RNA standards. In vitro transcription of these plasmids using T7 RNA polymerase yields RNA products carrying primer sites identical to those used to amplify target RNA, an approach initially described by Wang et al. (30). In addition to cytokine priming sites, pHCQ1 contains priming sites for $\beta$-actin, TCR $\alpha, \delta$, CD4, and CD8; pHCQ3 contains priming sites for IL-1R type 1, IL-1R type 2, TNF-R type 1, TNF-R type 2, and IL-6-R. The distance between specific $5^{\prime}$ and $3^{\prime}$ primer sequences and, therefore, the size of PCR amplification products, differ for standard and target RNAs (Table I). To construct the three plasmids, separate double-stranded DNA cassettes carrying $5^{\prime}$ or $3^{\prime}$ priming sites were generated using PCR-oligonucleotide overlap extension. Appropriate restriction site extensions at the ends of the cassettes were used to facilitate their sequential cloning into pGEM-3Zf $(-)$ (Promega, Madison, WI). Finally, to provide a poly (A) tail at the end of the standard RNA, the sequence 5' CTGCAG(A) ${ }_{15}$ AAGCTT (encoded by two complementary oligonucleotides) was inserted between the PstI and HindIII sites of the constructs. To ensure appropriate spacing, the constructs carry a spacer sequence separating the $5^{\prime}$ and $3^{\prime}$ priming sites. Nucleotide sequences of the 3 pHCQ constructs were confirmed by the dideoxy chain termination method using Sequenase (United States Biochemical Corp., Cleveland, $\mathrm{OH})$. To generate standard RNA, plasmids were linearized with HindII and transcribed in vitro using T7 RNA polymerase under conditions recommended by the supplier ( Stratagene, La Jolla, CA ). pHCQ1 yields an $840 \mathrm{nt}$, pHCQ2 a $413 \mathrm{nt}$, and pHCQ3 a 611 nt RNA product.

Oligonucleotide primers for PCR amplification. Sequences of the oligonucleotide primers used for PCR amplification and the size of the predicted PCR products from target RNA and standard RNA are shown in Table I. Primers were obtained as follows: IL- $1 \alpha$, IL- $1 \beta$, and IL-2 from Perkin Elmer Cetus (Norwalk, CT); IL-5, IL-6, IL-8, and TGF $\beta 1$ from Clontech (Palo Alto, CA); TNF $\alpha$, IFN- $\gamma$, GM-CSF, and $\beta$-actin from Stratagene. Primers for IL-10 were as described in (23). Primers for IL-4, MCP-1 and IL-12p40 were designed and synthesized in our laboratory. The primers either amplified fragments whose sizes, when obtained from cDNA, can be readily distinguished from those obtained from genomic DNA, or span exon-exon boundaries and, therefore, do not amplify genomic DNA.

RNA extraction and PCR amplification for quantitation of cytokine mRNA. RNA was extracted using acid guanidinium thiocyanate/phenol/ chloroform as described previously (7). Known quantities of standard RNA molecules were mixed with $1 \mu \mathrm{g}$ total cellular RNA and reverse transcribed at $37^{\circ} \mathrm{C}$ for $60 \mathrm{~min}$ in $20 \mu \mathrm{l}$ buffer containing $10 \mathrm{mM}$ Tris pH 8.3, $50 \mathrm{mM} \mathrm{KCl}, 5 \mathrm{mM} \mathrm{MgCl}_{2}, 1 \mathrm{mM}$ each of dATP, dCTP, dGTP, and dTTP, $20 \mathrm{U}$ RNasin ribonuclease inhibitor (Promega), $0.1 \mu \mathrm{g}$ oligo $(\mathrm{dT})_{15}$ (Boehringer Mannheim, Indianapolis, IN), and $50 \mathrm{U}$ M-MLV Reverse Transcriptase (Bethesda Research Laboratories, Gaithersburg, MD). Reactions were stopped by heat inactivation for $10 \mathrm{~min}$ at $95^{\circ} \mathrm{C}$ and chilled on ice. Subsequently, cDNA products were amplified by PCR in $100 \mu \mathrm{l}$ of $10 \mathrm{mM}$ Tris $\mathrm{pH} 8.3,50 \mathrm{mM} \mathrm{KCl}, 2 \mathrm{mM} \mathrm{MgCl}_{2}, 200$ $\mu \mathrm{M}$ each of dATP, dCTP, dGTP, and dTTP, in the presence of $25 \mathrm{pmol}$ each of 5' and 3' primer. Hot start PCR was used to increase specificity of the amplification. The temperature profile of the amplification consisted of 35 cycles of 1 min denaturation at $95^{\circ} \mathrm{C}$ and $2.5 \mathrm{~min}$ annealing and extension at $60^{\circ} \mathrm{C}$ (IL- $1 \alpha, \mathrm{IL}-1 \beta, \mathrm{IL}-2, \mathrm{IL}-6, \mathrm{IL}-8, \mathrm{IFN}-\gamma$, and MCP1 ), $65^{\circ} \mathrm{C}$ (IL-4, IL-5, IL-12p40, GM-CSF, and TGF $\beta 1$ ) or $72^{\circ} \mathrm{C}(\mathrm{IL}-$ $10, \mathrm{TNF} \alpha$, and $\beta$-actin). Negative controls were performed by omitting RNA from the cDNA synthesis and specific PCR amplification. As positive controls, RNA from cells known to abundantly express the respective mRNA were used: 5637 human bladder carcinoma cells for IL- $1 \alpha$, IL- $1 \beta$, IL-8 and GM-CSF; human chondrocytes for IL-6; HUT78 human T lymphoma cells for IL-2, TGF $\beta 1$, IFN- $\gamma$, and $\beta$-actin; PHAstimulated normal human PBMC for IL-4, IL-5, IL-10, and TNF $\alpha$; Caco-2 colon carcinoma cells for MCP-1 and a PMA-stimulated EBV transformed human B cell line for IL-12p40. PCR products were separated in 2\% NuSieve agarose (FMC Bioproducts, Rockland, ME) or in $5 \%$ polyacrylamide gels.

Quantitation of PCR products. Two methods were used to quantitate PCR products. In the first method (Fig. $2 A$ ) cellular target RNA and standard RNA were reverse transcribed together in a single reaction, after which serial two- or fivefold dilutions of the cDNA reaction mixture were prepared and cytokine transcripts were amplified by PCR. PCR products were visualized in gels by ethidium bromide staining and, when ${ }^{32} \mathrm{P} 5^{\prime}$ end-labeled primers were used, bands were excised from the gels and the incorporated radioactivity was determined using a scintillation counter. Radioactivity of the standard RNA PCR product was plotted against the number of standard RNA molecules in the PCR amplification, and radioactivity in the PCR product from target RNA was plotted against the amount of sample RNA used for PCR amplification using a double-logarithmic scale. With this method, a linear relationship was obtained between the number of standard RNA molecules or the amount of sample RNA, and the radioactivity incorporated into the PCR products. Moreover, curves for standard RNA and target RNA were parallel, indicating equal amplification efficiencies for both products.

In the second method (Fig. $2 \mathrm{~B}$ ) a constant amount of cellular target RNA was mixed with varying numbers of standard RNA transcripts and the mixtures were reverse transcribed, after which cDNA was amplified as described above. Each experiment used between $100 \mathrm{ng}$ and $1 \mu \mathrm{g}$ total cellular RNA. PCR products were electrophoresed in $2 \%$ NuSieve agarose gels and bands were visualized by ethidium bromide staining. Photographs of the gels were taken with Polaroid 665 film after which band intensities 


\begin{tabular}{|c|c|c|c|c|}
\hline \multirow[b]{2}{*}{$\begin{array}{l}\text { mRNA } \\
\text { species }\end{array}$} & \multirow[b]{2}{*}{5 ' primer } & \multirow[b]{2}{*}{$3^{\prime}$ primer } & \multicolumn{2}{|c|}{$\begin{array}{l}\text { Size of PCR } \\
\text { products }\end{array}$} \\
\hline & & & $\begin{array}{c}\text { Standard } \\
\text { RNA }\end{array}$ & $\begin{array}{l}\text { Target } \\
\text { RNA }\end{array}$ \\
\hline & & & \multicolumn{2}{|c|}{$b p$} \\
\hline IL-1 $\alpha$ & 5'-GTCTCTGAATCAGAAATCCTTCTATC-3' & 5'-CATGTCAAATTTCACTGCTTCATCC-3' & 530 & 420 \\
\hline $\mathrm{IL}-1 \beta$ & 5'-AAACAGATGAAGTGCTCCTTCCAGG-3' & 5'-TGGAGAACACCACTTGTTGCTCCA-3' & 528 & 388 \\
\hline IL-2 & 5'-GAATGGAATTAATAATTACAAGAATCCC-3' & 5'-TGTTTCAGATCCCTTTAGTTCCAG-3' & 299 & 222 \\
\hline IL-4 & 5'-AACACAACTGAGAAGGAAACCTTC-3' & 5'-GCTCGAACACTTTGAATATTTCTC-3' & 347 & 276 \\
\hline IL-5 & 5'-GCTTCTGCATTTGAGTTTGCTAGCT-3' & 5'-TGGCCGTCAATGTATTTCTTTATTAAG-3' & 372 & 293 \\
\hline IL-6 & 5'-ATGAACTCCTTCTCCACAAGCGC-3' & 5'-GAAGAGCCCTCAGGCTGGACTG-3' & 523 & 628 \\
\hline IL-8 & 5'-ATGACTTCCAAGCTGGCCGTGGCT-3' & 5'-TCTCAGCCCTCTTCAAAAACTTCTC-3' & 401 & 289 \\
\hline IL-10 & 5'-ATGCCCCAAGCTGAGAACCAAGACCCA-3' & 5'-TCTCAAGGGGCTGGGTCAGCTATCCCA-3' & 478 & 352 \\
\hline IL-12p40 & 5'-ATGTCGTAGAATTGGATTGGTATCCG-3' & 5'-GTACTGATTGTCGTCAGCCACCAGC-3' & 462 & 358 \\
\hline TNF $\alpha$ & 5'-CGGGACGTGGAGCTGGCCGAGGAG-3' & 5'-CACCAGCTGGTTATCTCTCAGCTC-3' & 432 & 355 \\
\hline TGF $\beta 1$ & 5'-GCCCTGGACACCAACTATTGCT-3' & 5'-AGGCTCCAAATGTAGGGGCAGG-3' & 246 & 161 \\
\hline IFN- $\gamma$ & 5'-ATGAAATATACAAGTTATATCTTGGCTTT-3' & 5'-GATGCTCTTCGACCTCGAAACAGCAT-3' & 384 & 501 \\
\hline MCP-1 & 5'-TCTGTGCCTGCTGCTCATAGC-3' & 5'-GGGTAGAACTGTGGTTCAAGAGG-3' & 381 & 510 \\
\hline GM-CSF & 5'-ACACTGCTGAGATGAATGAAACAGTAG-3' & 5'-TGGACTGGCTCCCAGCAGTCAAAGGGGATG-3' & 337 & 286 \\
\hline$\beta$-actin & 5'-TGACGGGGTCACCCACACTGTGCCCATCTA-3' & 5'-CTAGAAGCATTGCGGTGGACGATGGAGGG-3' & 520 & 661 \\
\hline
\end{tabular}

were quantitated by densitometry (BioRad GS-670 imaging densitometer; Bio Rad Instruments, Hercules, CA). In this approach, a point is determined where the starting number of standard RNA transcripts is equal to the starting number of cellular target RNA transcripts. To determine this point, the ratios of the band intensities of the PCR products from the standard RNA and target RNA (i.e., ratio standard RNA/target RNA band intensity) were plotted against the starting number of standard RNA molecules using a double logarithmic scale.

As shown in Fig. 2 for TNF $\alpha$ stimulated T84 cells, both methods yielded similar results when conducted in parallel. Such was the case also for lower abundance messages (data not shown). Moreover, both methods gave reliable inter-experimental results and, for all 14 cytokines, were sufficiently sensitive to quantitate fewer than $10^{3}$ transcripts/ $\mu \mathrm{g}$ cellular RNA. Since $10^{5}$ cells yielded $\sim 1 \mu \mathrm{g}$ cellular RNA, $10^{3}$ transcripts/ $\mu \mathrm{g}$ cellular RNA is equivalent, on average, to $\sim 1$ transcript/ 100 cells. Although technically the cytokine transcripts could be detected and quantitated at lower levels, this value was arbitrarily selected as a lower limit for the quantitative PCR analysis as lower levels are unlikely to be reflected by biologically meaningful protein production.

Cytokines, bacteria, and Giardia lamblia. The following cytokines, bacteria, and bacterial products were used in these studies: Recombinant human TNF $\alpha$ (rTNF $\alpha$ ) (Genentech, South San Francisco, CA), rIL-1 $\alpha$ (Immunex, Seattle, WA), rIFN- $\gamma$ (Biosource International, Camarillo, CA), bacterial lipopolysaccharide (LPS) from E. coli serotype O111:B4 (Sigma Chemical Co., St. Louis, MO), Salmonella dublin lane strain (31), Yersinia enterocolitica 08, Shigella dysenteriae (clinical isolates identified by the California State Health Department, Berkeley, CA), E. coli DH5 $\alpha$, E. coli serotype O29:NM (ATCC 43892), E. coli serotype O157 (ATCC 43894), Listeria monocytogenes 4b (ATCC 19115), and Enterococcus faecium (ATCC 35667) and Streptococcus bovis (ATCC 9809). G. lamblia trophozoites (provided by Dr. F. Gillin, UCSD) and bacterial strains were grown as described before $(32,33)$.

Colon epithelial cells and cell culture. Human T84 colonic epithelial cells (34) were a gift from $\mathrm{K}$. Dharmsathaphorn and were used between passage 16 and 35. Human HT29 colonic epithelial cells (HTB38), human SW620 colonic epithelial cells (CCL 227), and human Caco-2 ileocecal epithelial cells (HTB37) were obtained from American Type Culture Collection, Rockville, MD. Cell lines were maintained as described before (7).
Freshly isolated human epithelial cells and intraepithelial lymphocytes (IEL) from surgically resected colonic specimens were prepared as described before $(1,7)$. Epithelial cell preparations were free of contaminating B cells and monocytes/macrophages as assessed by flow cytometry using CD19/20 and CD14 markers. Cells were seeded at 1$2 \times 10^{6} / \mathrm{ml}$ in RPMI medium supplemented with $10 \%$ fetal calf serum and $2 \mathrm{mM}$ glutamine. For 48-h cultures, antibiotics were also added. Viability of the freshly isolated epithelial cells, as assessed by Trypan blue exclusion and staining with propidium iodide, was $>95 \%$ immediately after isolation, $>90 \%$ after $6-7 \mathrm{~h}$ in culture, $60-70 \%$ after $24 \mathrm{~h}$ in culture, and $20-30 \%$ after $48 \mathrm{~h}$ in culture. To assess the contribution of IEL to the secretion of cytokines in cultures, epithelial cells and IEL were isolated from the same surgical specimens and cytokine secretion was determined in separate cultures of each. IEL comprised $2-3 \%$ of the epithelial cell preparations whereas IEL preparations contained $>80 \%$ lymphocytes. IEL were cultured at $2 \times 10^{6} / \mathrm{ml}$. For assays of cytokine secretion, freshly isolated epithelial cells or IEL were cultured at $2 \times$ $10^{6} / \mathrm{ml}$ for $48 \mathrm{~h} \mathrm{(7).}$

Infection of colon epithelial cell monolayers with bacteria and $G$. lamblia. To infect colon epithelial cell lines with bacteria, cells grown to confluency in six-well plates were incubated with bacteria for $1 \mathrm{~h}$ to allow invasion to occur, after which the extracellular bacteria were removed by washing and cultures were incubated for an additional 2$3 \mathrm{~h}$ in the presence of $50 \mu \mathrm{g} / \mathrm{ml}$ of the nonmembrane permeant antibiotic gentamicin to kill the remaining extracellular, but not the intracellular, bacteria (33). In the case of $S$. bovis, $16 \mu \mathrm{g} / \mathrm{ml}$ ampicillin was used. Cells were lysed in distilled $\mathrm{H}_{2} \mathrm{O}$ and numbers of viable intracellular bacteria were determined as described before by plating of serial dilutions on agar (33). Cells were harvested for RNA extraction after the total 3-h period. To assess cytokine secretion, after the initial 1-h incubation with bacteria, cells were incubated for an additional $7 \mathrm{~h}$ in the presence of antibiotics, after which supernatants were harvested for cytokine ELISAs. Freshly isolated epithelial cells were plated at $10^{6}$ cells $/ \mathrm{ml}$ in a $1 \mathrm{ml}$ volume in six-well plates, and infected as above. Cells were incubated for 6 to $7 \mathrm{~h}$ in the presence of gentamicin before determining numbers of intracellular bacteria and cytokine secretion.

To infect T84 or Caco-2 cells with $G$. lamblia, trophozoites were washed with ice-cold DME, and $5 \times 10^{7}$ trophozoites were added to confluent monolayers in 10-cm dishes. After $5 \mathrm{~h}$, the monolayers were 
A
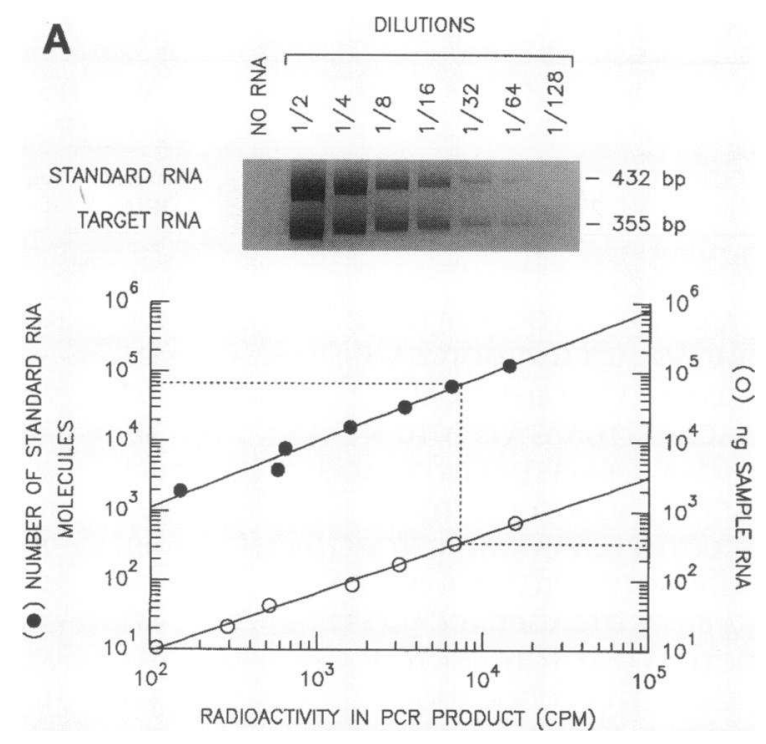

B

NUMBER OF STANDARD RNA MOLECULES
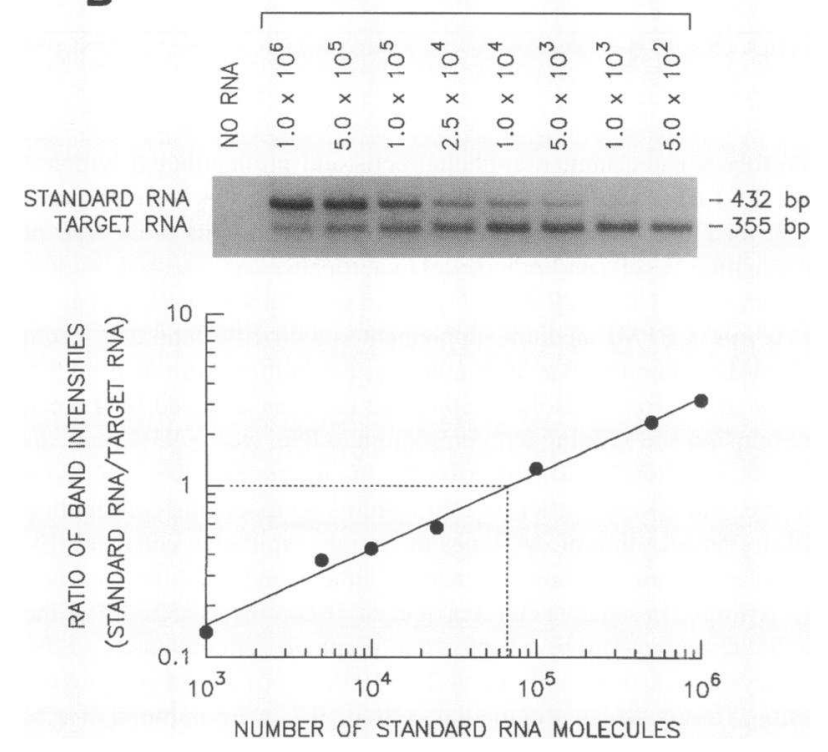

Figure 2. Comparison of two methods for competitive quantitative PCR. Method $1(A, t o p)$. In this example, total cellular RNA $(1.3 \mu \mathrm{g})$ from T84 cells stimulated with TNF $\alpha(100 \mathrm{ng} / \mathrm{ml})$ was reverse transcribed in the presence of $2.5 \times 10^{5}$ molecules of standard RNA and serial twofold dilutions of the cDNA mixture were amplified using TNF $\alpha$ specific primers (Table I). The $5^{\prime}$ primer was end-labeled with $\left[\gamma-{ }^{32} \mathrm{P}\right]$ ATP. PCR products were electrophoresed in a $5 \%$ polyacrylamide gel and visualized by ethidium bromide staining.

( $A$, bottom) Bands were excised from the gel, their radioactivity counted and results plotted. The amount of target RNA in the sample can be obtained from the graph by determining the number of standard RNA molecules and the amount of total sample RNA which yield identical amounts of incorporated radioactivity in their PCR products. As indicated, $340 \mathrm{ng}$ cellular RNA (dashed line, right vertical axis) and 7 $\times 10^{4}$ molecules of standard RNA (dashed line, left vertical axis) contained the same amount of radioactivity (horizontal axis) indicating that $1 \mu \mathrm{g}$ of cellular RNA from the stimulated T84 cells contained 2 $\times 10^{5}$ molecules of TNF $\alpha$ mRNA.

Method 2 ( $B$, top). Varying numbers of standard RNA molecules were co-reverse transcribed with a constant amount of cellular RNA ( $340 \mathrm{ng}$ ) from the same TNF $\alpha$ stimulated cells used in the experiment cooled on ice for $10 \mathrm{~min}$ and trophozoites were removed by washing with ice-cold PBS.

Cytokine assays. Cytokines in cell culture supernatants were assayed by enzyme linked immunosorbent assays (ELISAs). IL-8 ELISAs were done as described before $(7,33)$ and were sensitive to $20 \mathrm{pg} / \mathrm{ml}$. MCP1 ELISAs used optimal concentrations of polyclonal goat anti-human MCP-1 antibody (R \& D Systems, Minneapolis, MN) as the capturing antibody, and rabbit polyclonal MCP-1 antibody (Genzyme, Cambridge, MA) as the detection antibody. IL-6 ELISAs used optimal concentrations of monoclonal mouse anti-human IL-6 as capturing antibody (R \& D Systems) and rabbit polyclonal anti-human IL-6 antibody (Endogen, Boston, MA) as the detection antibody. Alkaline phosphatase labeled monoclonal mouse anti-rabbit immunoglobulin G (Sigma Chemical Co., St. Louis, MO) was used as a second antibody step. Bound alkaline phosphatase was visualized with the substrate p-nitrophenylphosphate (Sigma Chemical Co.). MCP-1 assays were sensitive to $0.5 \mathrm{pg} / \mathrm{ml}$, and IL-6 assays were sensitive to $5 \mathrm{pg} / \mathrm{ml}$. The TNF $\alpha$ ELISA (Quantikine HS; R \& D Systems) was sensitive to $0.2 \mathrm{pg} / \mathrm{ml}$, and the GM-CSF assay (Quantikine; R \& D Systems) was sensitive to $4 \mathrm{pg} / \mathrm{ml}$.

TGF $\beta 1$ bioassays were done using the mink lung cell line, Mv 1 Lu, (ATCC CCL 64) (35). Briefly, epithelial cell monolayers were cultured for $12 \mathrm{~h}$, with and without added stimuli, in DME supplemented with $1 \%$ fetal calf serum and $2 \mathrm{mM}$ glutamine, after which supernatants were harvested. Aliquots of the supernatants were transiently acidified with $65 \mathrm{mM} \mathrm{HCl}$ for $30 \mathrm{~min}$ at $4^{\circ} \mathrm{C}$, and neutralized with $65 \mathrm{mM}$ $\mathrm{NaOH}, 65 \mathrm{mM}$ Hepes. Serial dilutions of the supernatants were added to confluent CCL 64 monolayers in 96-well plates for $24 \mathrm{~h}$. For the final $4 \mathrm{~h}$ in culture, $0.5 \mu \mathrm{Ci}\left[{ }^{3} \mathrm{H}\right]$ thymidine was added to each well. Cells were harvested and incorporated radioactivity was determined by liquid scintillation counting. As a control for serum-derived TGF $\beta 1$ activity, culture medium alone containing $1 \%$ fetal calf serum was assayed in parallel and values were subtracted as background. The bioassay was sensitive to $100 \mathrm{pg} / \mathrm{ml}$ active TGF $\beta 1$.

\section{Results}

Expression of cytokine genes in control and TNF $\alpha$ stimulated cultures of T84, HT29, and SW620 cells. We first characterized the array of cytokine genes expressed in control cultures of T84, HT29 and SW620 cells. As shown in Table II, all three cell lines expressed mRNA for IL-8 and TGF $\beta 1$ in the absence of added stimuli. In addition, low levels of transcripts for TNF $\alpha$ and IL- $1 \beta$ were detected in T84 cells, those for IL- $1 \beta$ and GMCSF were found in HT29 cells and those for IL-10 were present in SW620 cells. All of the cell lines expressed detectable amounts of MCP-1 and IL- $1 \alpha$ mRNA but at levels $<10^{3}$ transcripts $/ \mu \mathrm{g}$. None of the cells expressed detectable levels of mRNA for IL-2, IL-4, IL-5, IL-6, IL-12p40, or IFN- $\gamma$ (data not shown).

in $A$. After reverse transcription, the cDNA reaction mixture was amplified using TNF $\alpha$ specific primers. PCR products were electrophoresed in $2 \%$ NuSieve agarose gels and bands were visualized by ethidium bromide staining and photographed using Polaroid 665 film. Negatives of the photographs were used to quantitate band intensities by densitometry. $(B$, bottom) Graph shows the ratio of band intensities of the PCR products from standard and target RNA plotted against the starting number of standard RNA molecules. When the ratio of band intensities equals 1 , the number of target RNA molecules is equivalent to the number of standard RNA molecules. In this example, $340 \mathrm{ng}$ cellular target RNA was equivalent to $6.8 \times 10^{4}$ molecules of standard RNA, indicating that $1 \mu \mathrm{g}$ of cellular RNA from the stimulated T84 cells contained $2 \times 10^{5}$ molecules of TNF $\alpha$ mRNA. 
Table II. Cytokine mRNA Levels in Control or TNF $\alpha$ Stimulated T84, HT29, and SW620 Cells*

\begin{tabular}{|c|c|c|c|c|c|c|c|c|c|}
\hline \multirow[b]{3}{*}{ Cytokines } & \multicolumn{3}{|c|}{ T84 cells } & \multicolumn{3}{|c|}{ HT29 cells } & \multicolumn{3}{|c|}{ SW620 cells } \\
\hline & \multicolumn{2}{|c|}{ Transcripts $/ \mu \mathrm{g}^{\mathrm{t}}$} & \multirow{2}{*}{$\begin{array}{l}\text { Ratio of TNF } \alpha \\
\text { stimulated/control }\end{array}$} & \multicolumn{2}{|c|}{ Transcripts/ $\mu \mathrm{g}$} & \multirow{2}{*}{$\begin{array}{c}\text { Ratio of TNF } \alpha \\
\text { stimulated/control }\end{array}$} & \multicolumn{2}{|c|}{ Transcripts/ $\mu \mathrm{g}$} & \multirow{2}{*}{$\begin{array}{l}\text { Ratio of TNF } \alpha \\
\text { stimulated/control }\end{array}$} \\
\hline & Control & $+\mathrm{TNF} \alpha$ & & Control & $+\mathrm{TNF} \alpha$ & & Control & $+\mathrm{TNF} \alpha$ & \\
\hline IL-8 & $8 \times 10^{3}$ & $5 \times 10^{5}$ & 63 & $8 \times 10^{4}$ & $8 \times 10^{6}$ & 100 & $3 \times 10^{4}$ & $6 \times 10^{5}$ & 20 \\
\hline МСР-1 & $<10^{3}$ & $2 \times 10^{5}$ & $>200$ & $<10^{3}$ & $\mathrm{NT}^{\prime \prime}$ & $\mathrm{NC}^{\prime}$ & $<10^{3}$ & $9 \times 10^{3}$ & $>9$ \\
\hline TNF $\alpha$ & $1 \times 10^{3}$ & $2 \times 10^{5}$ & 200 & $<10^{3}$ & $6 \times 10^{4}$ & $>60$ & $<10^{3}$ & $4 \times 10^{4}$ & $>40$ \\
\hline GM-CSF & $<10^{3}$ & $1 \times 10^{4}$ & $>10$ & $4 \times 10^{3}$ & $3 \times 10^{5}$ & 75 & $<10^{3}$ & $3 \times 10^{4}$ & $>30$ \\
\hline $\mathrm{IL}-1 \beta$ & $1 \times 10^{3}$ & $1 \times 10^{4}$ & 10 & $1 \times 10^{3}$ & $2 \times 10^{3}$ & 2 & $<10^{3}$ & $<10^{3}$ & NC \\
\hline IL- $1 \alpha$ & $<10^{3}$ & $3 \times 10^{3}$ & $>3$ & $<10^{3}$ & $<10^{3}$ & NC & $<10^{3}$ & $<10^{3}$ & $\mathrm{NC}$ \\
\hline IL-10 & $<10^{3}$ & $<10^{3}$ & $\mathrm{NC}$ & $<10^{3}$ & $<10^{3}$ & $\mathrm{NC}$ & $3 \times 10^{3}$ & $5 \times 10^{3}$ & 1.7 \\
\hline TGF $\beta 1$ & $5 \times 10^{4}$ & $5 \times 10^{4}$ & 1 & $4 \times 10^{5}$ & $7 \times 10^{5}$ & 1.8 & $1 \times 10^{6}$ & $9 \times 10^{5}$ & 0.9 \\
\hline
\end{tabular}

* Cultures of T84, HT29, or SW620 cells were stimulated with TNF $\alpha(200 \mathrm{ng} / \mathrm{ml})$ or no additional stimuli were added for $16 \mathrm{~h}$ after which cellular RNA was prepared as described in Methods. ${ }^{\ddagger}$ Values are numbers of cytokine transcripts/ $\mu \mathrm{g}$ total cellular RNA. $10^{3}$ transcripts $/ \mu \mathrm{g}$ cellular RNA is equivalent to $\sim 1$ transcript/100 cells and was arbitrarily taken as a lower limit for quantitation. ${ }^{8}$ Not shown, IL-2, IL-4, IL-5, IL-6, IL-12p40, and IFN- $\gamma$ transcripts could not be detected in any of these cell lines under control conditions, or following TNF $\alpha$ stimulation. "NT, not tested.

${ }^{\top} N C$, value cannot be calculated.

mRNA levels for four cytokines were markedly increased by TNF $\alpha$ stimulation in all three cell lines. As shown in Table II, TNF $\alpha$ stimulation resulted in a $20-100$-fold increase in steady state levels of mRNA for IL-8, a greater than 9-200-fold increase in MCP-1 mRNA levels, a $>40-200$-fold increase in TNF $\alpha$ message levels and a greater than 10-75-fold increase in GM-CSF mRNA levels in the cell lines as assayed $16 \mathrm{~h}$ after stimulation. In contrast, upregulation of IL- $1 \beta, \mathrm{IL}-1 \alpha$, and IL10 was variable among the cell lines and never greater than $10-$ fold. TNF $\alpha$ did not upregulate expression of TGF $\beta 1$ mRNA. As in control cultures, none of the cell lines expressed mRNA for IL-2, IL-4, IL-5, IL-6, IL-12p40, or IFN- $\gamma$ following TNF $\alpha$ stimulation.

Increased cytokine mRNA levels in T84 and Caco-2 cells in response to bacterial invasion. To assess changes in cytokine gene expression in epithelial cells in response to bacterial infection, T84 cell monolayers were infected with the invasive bacteria $S$. dublin or with noninvasive bacterial strains ( $E$. coli $\mathrm{DH} 5 \alpha$, $E$. faecium) and cytokine mRNA levels were determined $3 \mathrm{~h}$ after infection. As shown in Table III, infection of T84 cells with the invasive gram-negative bacterium $S$. dublin resulted in increased mRNA levels of IL-8, MCP-1, TNF $\alpha$, and GM-CSF. In contrast, neither the noninvasive gram-negative bacterium $E$. coli $\mathrm{DH} 5 \alpha$, the noninvasive gram-positive bacterium $E$. faecium, nor bacterial LPS (data not shown) influenced cytokine mRNA levels expressed by these cells. Further, constitutive levels of mRNA for TGF $\beta 1$ and $\beta$-actin were not increased by $S$. dublin invasion and $\mathrm{IL}-2, \mathrm{IL}-4, \mathrm{IL}-5, \mathrm{IL}-6, \mathrm{IL}-12 \mathrm{p} 40$, and IFN- $\gamma$ mRNA were not detected after co-culture of T84 cells with invasive or noninvasive bacterial strains. Similarly, increased mRNA levels for IL-8, MCP-1, TNF $\alpha$, and GM-CSF were found in Caco-2 cells following invasion by $S$. dublin (data not shown).

Trophozoites of G. lamblia, a noninvasive protozoan parasite, attach to, but do not invade intestinal epithelial cells, and infection is not accompanied by an acute inflammatory response. To explore whether $G$. lamblia infection could upregulate epithelial cell cytokine expression, monolayers of T84 or Caco- 2 cells were co-cultured with $G$. lamblia trophozoites. Co- culture of these cells with $G$. lamblia did not alter expression of the cytokines studied herein as assessed by RT-PCR (data not shown).

Regulated secretion of $I L-8, M C P-1, T N F \alpha$, and GM-CSF by colon epithelial cells. The above studies indicated that mRNA levels of four cytokines were coordinately upregulated in colon epithelial cells in response to TNF $\alpha$ stimulation and Salmonella invasion. To determine if increased mRNA levels for these cytokines were paralleled by increased protein secretion, cytokine secretion by the cell lines in response to bacterial invasion or stimulation with proinflammatory agonists was studied.

As shown in Table IV, TNF $\alpha$ secretion by T84 cells was increased following bacterial invasion of the monolayers with $Y$. enterocolitica, S. dublin, enteroinvasive $E$. coli and $S$. dysenteriae. The quantity of TNF $\alpha$ secreted paralleled the extent of bacterial entry, as reflected by the number of recovered intracellular bacteria. In contrast, infection of the monolayers with noninvasive $E$. coli or stimulation with bacterial LPS did not increase TNF $\alpha$ secretion by $\mathrm{T} 84$ cells.

As shown in Table V, infection of Caco-2 monolayers with several different strains of invasive bacteria upregulated both MCP-1 and IL-8 secretion. MCP-1 secretion was also increased following stimulation of this cell line with IL- $1 \alpha$ and, as noted before (7), IL-1 stimulation upregulated IL-8 secretion. In contrast, IFN- $\gamma$ had no effect on the expression of either of these chemokines. Moreover, Caco- 2 cells were poorly responsive to LPS and TNF $\alpha$ stimulation (7, data not shown).

HT29 monolayers were used to ask whether secretion of GM-CSF was increased following bacterial invasion or TNF $\alpha$ stimulation, since HT29 cells, compared with the other cell lines, expressed the highest levels of mRNA for GM-CSF after TNF $\alpha$ stimulation ( Table II). In addition, HT29 cells were used to assess secretion of the full array of all four proinflammatory cytokines by one cell line. As shown in Table VI, secretion of GM-CSF, IL-8, MCP-1 and TNF $\alpha$ was markedly increased in HT29 monolayers infected with the invasive gram negative bacteria S. dysenteriae, $Y$. enterocolitica, S. dublin, lane and enteroinvasive $E$. coli. Moreover, TNF $\alpha$ stimulation increased secre- 


\begin{tabular}{|c|c|c|c|c|c|c|c|c|c|}
\hline \multirow[b]{3}{*}{ Cytokines $^{\ddagger}$} & \multirow{3}{*}{$\frac{\text { Control }}{\underset{\substack{\text { Transcripts/ } \\
\mu \mathrm{g}^{8}}}{ }}$} & \multicolumn{8}{|c|}{ Additions to culture } \\
\hline & & \multicolumn{2}{|c|}{ S. dublin } & \multicolumn{2}{|c|}{ E. coli $\mathrm{DH} 5 \alpha$} & \multicolumn{2}{|c|}{ E. faecium } & \multicolumn{2}{|c|}{$\mathrm{TNF} \alpha$} \\
\hline & & $\begin{array}{c}\text { Transcripts/ } \\
\mu \mathrm{g}\end{array}$ & $\begin{array}{l}\text { Ratio infected/ } \\
\text { control }\end{array}$ & $\begin{array}{c}\text { Transcripts/ } \\
\mu \mathrm{g}\end{array}$ & $\begin{array}{l}\text { Ratio infected/ } \\
\text { control }\end{array}$ & $\begin{array}{c}\text { Transcripts/ } \\
\mu \mathrm{g}\end{array}$ & $\begin{array}{c}\text { Ratio infected/ } \\
\text { control }\end{array}$ & Transcripts $/ \mu \mathrm{g}$ & $\begin{array}{l}\text { Ratio stimulated } \\
\text { control }\end{array}$ \\
\hline IL-8 & $1 \times 10^{5}$ & $2 \times 10^{6}$ & 20 & $1 \times 10^{5}$ & 1 & $1 \times 10^{5}$ & 1 & $1 \times 10^{7}$ & 100 \\
\hline MCP-1 & $<10^{3}$ & $3 \times 10^{4}$ & $>30$ & $<10^{3}$ & $\mathrm{NC}^{\|}$ & $<10^{3}$ & $\mathrm{NC}$ & $2 \times 10^{5}$ & $>200$ \\
\hline $\mathrm{TNF} \alpha$ & $<10^{3}$ & $1 \times 10^{5}$ & $>100$ & $<10^{3}$ & NC & $1 \times 10^{3}$ & $>1$ & $5 \times 10^{5}$ & $>500$ \\
\hline GM-CSF & $<10^{3}$ & $1 \times 10^{5}$ & $>100$ & $<10^{3}$ & NC & $<10^{3}$ & $\mathrm{NC}$ & $3 \times 10^{4}$ & $>30$ \\
\hline IL- $1 \beta$ & $5 \times 10^{3}$ & $8 \times 10^{3}$ & 1.6 & $2 \times 10^{3}$ & 0.4 & $3 \times 10^{3}$ & 0.6 & $2 \times 10^{5}$ & 40 \\
\hline IL-1 $\alpha$ & $<10^{3}$ & $2 \times 10^{3}$ & $>2$ & $<10^{3}$ & NC & $<10^{3}$ & $\mathrm{NC}$ & $1 \times 10^{4}$ & $>10$ \\
\hline TGF $\beta 1$ & $3 \times 10^{6}$ & $2 \times 10^{6}$ & 0.7 & $1 \times 10^{6}$ & 0.3 & $2 \times 10^{6}$ & 0.7 & $8 \times 10^{5}$ & 0.3 \\
\hline$\beta$-Actin & $7 \times 10^{7}$ & $3 \times 10^{7}$ & 0.4 & $4 \times 10^{7}$ & 0.6 & $3 \times 10^{7}$ & 0.4 & $6 \times 10^{7}$ & 0.9 \\
\hline
\end{tabular}

* Cultures were infected with bacteria as described in Methods or stimulated with TNF $\alpha(200 \mathrm{ng} / \mathrm{ml})$ for $3 \mathrm{~h}$. ${ }^{\ddagger}$ Not shown, IL-2, IL-4, IL-5, IL6 , IL-10, IL-12p40, and IFN- $\gamma$ transcripts were not detected after infection with bacteria or after TNF $\alpha$ stimulation. ${ }^{8}$ Values are the number of cytokine transcripts $/ \mu \mathrm{g}$ total cellular RNA. " $N C$, value cannot be calculated. " $\beta$-actin is included as a control since it is a constitutively expressed "housekeeping" gene.

tion of GM-CSF, IL-8, and MCP-1. We also found increased cytokine secretion in response to the noninvasive gram negative bacterial strains, $E$. coli $\mathrm{O} 157$ and $E$. coli DH5 $\alpha$, in HT29 cells but not in the other cell lines tested (Tables IV and V.) This response was significantly lower than that noted after infection with invasive gram negative bacteria and may reflect stimulation by cell wall components such as LPS. Consistent with the data in Table VI, we previously demonstrated that HT29 cells secreted small amounts of IL-8 in response to LPS stimulation (7). The data in Table VI further demonstrate that HT29 cells secrete small amounts of GM-CSF, MCP-1 and TNF $\alpha$ in re-

Table IV. TNF $\alpha$ Secretion by T84 Cells after Coculture with Bacteria*

\begin{tabular}{|c|c|c|c|c|}
\hline \multirow[b]{2}{*}{ Additions to culture } & \multirow{2}{*}{$\frac{\begin{array}{c}\text { Bacterial } \\
\text { inoculum }\end{array}}{\begin{array}{c}\text { Number/ } \\
\text { well }^{\ddagger}\end{array}}$} & \multicolumn{2}{|c|}{$\begin{array}{l}\text { Intracellular bacteria } \\
\text { recovered }\end{array}$} & \multirow[b]{2}{*}{$\begin{array}{c}\text { TNF } \alpha \\
\text { secreted }\end{array}$} \\
\hline & & $\begin{array}{c}\text { Number/ } \\
\text { well }^{\ddagger}\end{array}$ & $\begin{array}{l}\text { Percent of } \\
\text { inoculum }\end{array}$ & \\
\hline & & & & $p g / m l$ \\
\hline Y. enterocolitica & $5.6 \times 10^{8}$ & $1.5 \times 10^{8}$ & 27 & $5.4 \pm 0.5^{5}$ \\
\hline $\begin{array}{l}\text { E. coli O29:NM } \\
\text { (enteroinvasive) }\end{array}$ & $7.6 \times 10^{8}$ & $3.1 \times 10^{7}$ & 4.1 & $3.8 \pm 0.1$ \\
\hline S. dublin lane & $8.6 \times 10^{7}$ & $1.6 \times 10^{6}$ & 1.9 & $2.7 \pm 0.2$ \\
\hline S. dysenteriae & $6.4 \times 10^{8}$ & $3.3 \times 10^{6}$ & 0.52 & $1.3 \pm 0.1$ \\
\hline $\begin{array}{l}\text { E. coli DH5 } \alpha \\
\text { (nonpathogenic) }\end{array}$ & $3.1 \times 10^{8}$ & $1.0 \times 10^{4}$ & 0.0032 & $<0.2$ \\
\hline $\begin{array}{l}\text { E. coli } \mathrm{O} 157 \\
\text { (enterohemorrhagic) }\end{array}$ & $6.8 \times 10^{8}$ & $1.2 \times 10^{4}$ & 0.0018 & $<0.2$ \\
\hline LPS & - & - & - & $<0.2$ \\
\hline None & - & - & - & $0.3 \pm 0.1$ \\
\hline
\end{tabular}

* Confluent cultures of T84 cells were infected with bacterial strains as shown. Numbers of intracellular bacteria and cytokine secretion were determined as outlined in the Methods. Parallel cultures were stimulated with LPS $(10 \mu \mathrm{g} / \mathrm{ml})$ for $7 \mathrm{~h}$. Data are from a representative experiment. Comparable results were obtained in two additional experiments. ${ }^{\ddagger}$ Numbers are means of duplicate cultures. ${ }^{8}$ Numbers are means \pm SEM of triplicate cultures. sponse to LPS stimulation. Expression of all four cytokines was coordinately upregulated in response to infection with the invasive gram positive bacteria, $L$. monocytogenes, but not in response to infection with the noninvasive gram positive bacterium, $S$. bovis. This finding confirms the importance of bacterial invasion for expression of proinflammatory cytokines in HT29 cells, independent of an LPS effect.

In contrast to the proinflammatory cytokines, and consistent with the RT-PCR results (Table II), TGF $\beta 1$ secretion was not increased in the cell lines in response to TNF $\alpha$ or IL- $1 \beta$ stimulation (Table VII). Moreover, in contrast to rat epithelial cells (36), IL-2 did not stimulate TGF $\beta 1$ secretion by the human cell lines.

Bacterial invasion and cytokine production by freshly isolated human colon epithelial cells. We next determined if bacteria entered normal colon epithelial cells in culture, as was the case for the epithelial cell lines. As shown in Table VIII, freshly isolated colon epithelial cells were invaded by pathogenic $Y$. enterocolitica, $S$. dublin and, to a lesser extent, $L$. monocytogenes, but not by nonpathogenic $E$. coli $\mathrm{DH} 5 \alpha$. Moreover, the numbers of intracellular bacteria were similar to those in the cell lines.

To determine if the same array of cytokines that are expressed in colon epithelial cell lines can be produced also by freshly isolated human colon epithelial cells, cells isolated from seven different individuals were cultured in vitro for $48 \mathrm{~h}$. We previously reported that IL-8 (7) and GM-CSF (37) can be produced by freshly isolated human colon epithelial cells. The data in Table IX show MCP-1 and TNF $\alpha$ secretion by these cells. Since the epithelial cell preparations contained 2-3\% contaminating intraepithelial lymphocytes (IEL), we also analyzed IEL from some of the same surgical specimens for their ability to produce MCP-1 and TNF $\alpha$. IEL secreted only low amounts of these cytokines indicating that, in the epithelial cell cultures, TNF $\alpha$ and MCP-1 were produced mainly by the epithelial cells.

In further experiments, we asked if MCP-1 and IL-8 secretion by freshly isolated human colon epithelial cells, like that of the cell lines, was upregulated in response to bacterial inva- 


\begin{tabular}{|c|c|c|c|c|c|}
\hline \multirow[b]{2}{*}{ Additions to culture } & \multirow{2}{*}{$\begin{array}{c}\begin{array}{c}\text { Bacterial } \\
\text { inoculum }\end{array} \\
\text { Number/well }^{\ddagger}\end{array}$} & \multicolumn{2}{|c|}{ Intracellular bacteria recovered } & \multicolumn{2}{|c|}{ Chemokines secreted } \\
\hline & & Number/well ${ }^{\ddagger}$ & Percent of inoculum & MCP-1 & IL-8 \\
\hline & & & & \multicolumn{2}{|c|}{$p g / m l$} \\
\hline S. dublin lane & $9.5 \times 10^{7}$ & $3.4 \times 10^{6}$ & 3.6 & $198.0 \pm 1.5^{8}$ & $1412 \pm 50^{8}$ \\
\hline Y. enterocolitica & $9.6 \times 10^{7}$ & $3.1 \times 10^{7}$ & 32 & $97.0 \pm 2.2$ & $542 \pm 64$ \\
\hline L. monocytogenes & $2.4 \times 10^{9}$ & $1.1 \times 10^{7}$ & 0.46 & $80.3 \pm 4.9$ & $583 \pm 13$ \\
\hline E. coli $\mathrm{O} 29: \mathrm{NM}$ (enteroinvasive) & $3.6 \times 10^{8}$ & $6.4 \times 10^{7}$ & 18 & $45.7 \pm 1.0$ & $279 \pm 8$ \\
\hline S. dysenteriae & $8.2 \times 10^{8}$ & $8.4 \times 10^{5}$ & 0.10 & $25.6 \pm 0.5$ & $115 \pm 10$ \\
\hline E. coli $\mathrm{O} 157$ (enterohemorrhagic) & $5.3 \times 10^{8}$ & $1.3 \times 10^{3}$ & 0.00024 & $17.6 \pm 1.0$ & $69 \pm 2$ \\
\hline LPS & - & - & - & $17.1 \pm 0.6$ & $20 \pm 2$ \\
\hline $\mathrm{IL}-1 \alpha$ & - & - & - & $217.2 \pm 5.0$ & $1181 \pm 27$ \\
\hline IFN- $\gamma$ & - & - & - & $12.2 \pm 0.6$ & $<20$ \\
\hline None & - & - & - & $11.9 \pm 0.5$ & $<20$ \\
\hline
\end{tabular}

* Confluent cultures of Caco-2 cells were infected with bacterial strains as shown. Numbers of intracellular bacteria and cytokine secretion were determined as outlined in the Methods. Parallel cultures were stimulated with LPS $(10 \mu \mathrm{g} / \mathrm{ml}), \mathrm{IL}-1 \alpha(10 \mathrm{ng} / \mathrm{ml})$, or IFN- $\gamma(40 \mathrm{ng} / \mathrm{ml})$ for $7 \mathrm{~h}$. IL1 was used for stimulation of Caco-2 instead of TNF $\alpha$ as Caco-2 cells were previously reported to upregulate IL-8 secretion in response to IL-1, but not in response to TNF $\alpha$ stimulation (7). Data are from representative experiments. Comparable results were obtained in two additional experiments. ${ }^{\ddagger}$ Numbers are means of duplicate cultures. ${ }^{8}$ Numbers are means \pm SEM of triplicate cultures.

sion or IL-1 $\beta$ stimulation, since those chemokines likely provide early signals for initiation of a mucosal inflammatory response. As shown in Table X, stimulated cytokine secretion by normal epithelial cells was of a similar order of magnitude to that of the Caco-2 cell line (Table V) and, as reported before, the T84 cell line (7). Moreover, MCP-1 and IL-8 secretion increased in response to co-culture with the invasive bacteria $Y$. enterocolitica and L. monocytogenes or stimulation with IL-
$1 \beta$. However, relative increases in MCP-1 and IL-8 secretion over background levels in freshly isolated cells were not as great as with cell lines, which may reflect the generally higher background levels of MCP-1 and IL-8 seen with freshly isolated cells. This notion is supported by the results from Exp. 2 (Table $\mathrm{X}$ ) which shows 5-8-fold higher background levels compared with Exp. 1 and, concurrently, less marked relative increases in chemokine secretion in response to bacterial invasion. Fi-

Table VI. Secretion of GM-CSF, IL-8, MCP-1, and TNF $\alpha$ by HT29 Cells*

\begin{tabular}{|c|c|c|c|c|c|c|c|}
\hline & \multirow{2}{*}{$\begin{array}{c}\begin{array}{c}\text { Bacterial } \\
\text { inoculum }\end{array} \\
\text { Number/well }^{t}\end{array}$} & \multicolumn{2}{|c|}{$\begin{array}{l}\text { Intracellular bacteria } \\
\text { recovered }\end{array}$} & \multicolumn{4}{|c|}{ Cytokines secreted } \\
\hline & & Number/well ${ }^{*}$ & $\begin{array}{l}\text { Percent of } \\
\text { inoculum }\end{array}$ & GM-CSF & IL-8 & MCP-1 & $\mathrm{TNF} \alpha$ \\
\hline & & & & $p g / m l$ & $n g / m l$ & $p g / m l$ & $p g / m l$ \\
\hline \multicolumn{8}{|l|}{ Gram negative bacteria } \\
\hline S. dysenteriae & $6.2 \times 10^{8}$ & $1.5 \times 10^{6}$ & 0.24 & $402 \pm 2^{8}$ & $80.5 \pm 3.1^{8}$ & $81.3 \pm 2.9^{8}$ & $101.4 \pm 10.6^{8}$ \\
\hline Y. enterocolitica & $4.5 \times 10^{8}$ & $2.6 \times 10^{8}$ & 57.8 & $370 \pm 16$ & $72.5 \pm 1.6$ & $155.0 \pm 5.0$ & $188.7 \pm 18.1$ \\
\hline S. dublin lane & $6.2 \times 10^{7}$ & $2.1 \times 10^{6}$ & 3.4 & $363 \pm 13$ & $42.4 \pm 1.2$ & $128.0 \pm 1.0$ & $71.0 \pm 2.3$ \\
\hline E. coli O29:NM (enteroinvasive) & $2.5 \times 10^{8}$ & $7.1 \times 10^{5}$ & 0.28 & $251 \pm 3$ & $41.9 \pm 5.1$ & $68.0 \pm 0.9$ & $37.0 \pm 0.9$ \\
\hline E. coli $\mathrm{O} 157$ (enterohemorrhagic) & $1.9 \times 10^{8}$ & $3.5 \times 10^{3}$ & 0.0018 & $25 \pm 2$ & $5.9 \pm 0.2$ & $20.7 \pm 0.7$ & $7.7 \pm 0.4$ \\
\hline E. coli DH5 $\alpha$ (nonpathogenic) & $1.0 \times 10^{8}$ & $4.3 \times 10^{3}$ & 0.0043 & $21 \pm 2$ & $4.7 \pm 0.06$ & $21.4 \pm 1.1$ & $4.3 \pm 0.2$ \\
\hline \multicolumn{8}{|l|}{ Gram positive bacteria } \\
\hline L. monocytogenes & $1.4 \times 10^{9}$ & $4.5 \times 10^{7}$ & 3.2 & $31 \pm 2$ & $17.1 \pm 0.1$ & $12.3 \pm 0.7$ & $17.9 \pm 1.0$ \\
\hline S. bovis & $2.2 \times 10^{8}$ & $1.6 \times 10^{4}$ & 0.0073 & $6 \pm 1$ & $0.5 \pm 0.03$ & $2.7 \pm 0.1$ & $0.7 \pm 0.1$ \\
\hline \multicolumn{8}{|l|}{ Other stimuli } \\
\hline LPS & - & - & - & $5 \pm 1$ & $2.0 \pm 0.1$ & $5.0 \pm 0.2$ & $1.1 \pm 0.1$ \\
\hline TNF $\alpha$ & - & - & - & $919 \pm 28$ & $230.5 \pm 11.5$ & $909.0 \pm 8.0$ & ND" \\
\hline None & - & - & - & $<4$ & $0.5 \pm 0.02$ & $2.4 \pm 0.1$ & $0.3 \pm 0.1$ \\
\hline
\end{tabular}

* Confluent cultures of HT29 cells were infected with bacterial strains as shown. Intracellular bacteria and cytokine secretion were determined as outlined in the Methods. Parallel cultures were stimulated with LPS $(10 \mu \mathrm{g} / \mathrm{ml})$, or TNF $\alpha(200 \mathrm{ng} / \mathrm{ml})$ for $7 \mathrm{~h}$. Data are from a representative experiment. Comparable results were obtained in an additional experiment. ${ }^{\ddagger}$ Numbers are means of duplicate cultures. ${ }^{8}$ Numbers are means \pm SEM of triplicate cultures. "ND, not done since TNF $\alpha$ was added exogenously. 
Table VII. Secretion of Latent TGFB1 by Colon Epithelial Cell Lines*

\begin{tabular}{llcc}
\hline Cell line & Additions to culture & TGF $\beta$ 1 secreted & IL-8 secreted \\
\hline \multirow{4}{*}{ Caco-2 } & & $p g / m l$ & $p g / m l$ \\
& None & 510 & $<20$ \\
& IL-1 $\beta$ & 510 & 880 \\
SW620 & IL-2 & 470 & $<20$ \\
& None & 730 & NT $^{\ddagger}$ \\
& TNF $\alpha$ & 550 & NT \\
T84 & IL-2 & 850 & NT \\
& None & $<100$ & 500 \\
& TNF $\alpha$ & $<100$ & 6,040 \\
& IL-2 & $<100$ & 450 \\
\hline
\end{tabular}

* Representative experiment in which confluent monolayers of colon epithelial cells were grown in media containing $1 \%$ fetal calf serum and stimulated with $10 \mathrm{ng} / \mathrm{ml} \mathrm{IL-1 \beta ,50} \mathrm{ng/ml} \mathrm{IL-2,} \mathrm{or} 100 \mathrm{ng} / \mathrm{ml} \mathrm{TNF} \alpha$ for $12 \mathrm{~h}$ as described in Methods. Active and latent TGF $\beta 1$ concentrations were determined by bioassay. Only latent TGF $\beta 1$ was secreted by the cell lines. IL-8 concentrations were determined by ELISA. ${ }^{\ddagger} N T$, not tested. We previously reported TNF $\alpha$ increases IL-8 secretion by SW620 cells (7).

nally, we note that colon epithelial cells were previously reported to produce IL- 6 in vivo by immunostaining (9). Consistent with this, freshly isolated intestinal epithelial cells, in contrast to the cell lines, produced IL-6 and secretion of this cytokine was upregulated in response to microbial invasion and IL- $1 \beta$ stimulation.

Table VIII. Entry of Invasive Bacteria into Freshly Isolated Colon Epithelial Cells

\begin{tabular}{|c|c|c|c|c|}
\hline \multirow[b]{2}{*}{ Experiment } & \multirow[b]{2}{*}{$\begin{array}{l}\text { Bacteria added to } \\
\text { cultures }\end{array}$} & \multirow{2}{*}{$\begin{array}{c}\text { Bacterial } \\
\text { inoculum } \\
\text { (number/well) }\end{array}$} & \multicolumn{2}{|c|}{$\begin{array}{l}\text { Intracellular bacteria } \\
\text { recovered }\end{array}$} \\
\hline & & & $\begin{array}{c}\text { Number/ } \\
\text { well }\end{array}$ & $\begin{array}{l}\text { Percent of } \\
\text { inoculum }\end{array}$ \\
\hline \multirow[t]{4}{*}{1} & $Y$. enterocolitica & $2.5 \times 10^{8}$ & $2.3 \times 10^{7}$ & 9.2 \\
\hline & S. dublin & $2 \times 10^{7}$ & $3.1 \times 10^{6}$ & 15.5 \\
\hline & L. monocytogenes & $5 \times 10^{7}$ & $9.0 \times 10^{3}$ & 0.018 \\
\hline & E. coli $\mathrm{DH} 5 \alpha$ & $2.5 \times 10^{8}$ & $4.0 \times 10^{2}$ & 0.00016 \\
\hline \multirow[t]{3}{*}{2} & $Y$. enterocolitica & $5 \times 10^{7}$ & $1.7 \times 10^{6}$ & 3.4 \\
\hline & S. dublin & $2 \times 10^{7}$ & $2.4 \times 10^{5}$ & 1.2 \\
\hline & E. coli $\mathrm{DH} 5 \alpha$ & $5 \times 10^{7}$ & $<10^{2}$ & $<0.0002$ \\
\hline \multirow[t]{5}{*}{3} & Y. enterocolitica & $2.5 \times 10^{8}$ & $1.9 \times 10^{7}$ & 7.6 \\
\hline & & $5 \times 10^{7}$ & $7.2 \times 10^{6}$ & 14.4 \\
\hline & & $1.3 \times 10^{7}$ & $1.4 \times 10^{6}$ & 10.8 \\
\hline & E. coli $\mathrm{DH} 5 \alpha$ & $2.5 \times 10^{8}$ & $8.0 \times 10^{2}$ & 0.00032 \\
\hline & & $5 \times 10^{7}$ & $9.0 \times 10^{1}$ & 0.00018 \\
\hline
\end{tabular}

* Intestinal epithelial cells were isolated from surgically resected colon specimens, as described in Methods. Cells were seeded at $10^{6} \%$ well in a $1 \mathrm{ml}$ volume using six-well plates and infected for $1 \mathrm{~h}$ with different bacterial strains, as indicated in the Table. Subsequently, bacteria were removed and cultures were further incubated for 6-7 $\mathrm{h}$ in the presence of gentamicin. Epithelial cells were lysed in water and the number of viable intracellular bacteria was determined.
Table IX. Secretion of TNF $\alpha$ and MCP-1 by Freshly Isolated Intestinal Epithelial Cells

\begin{tabular}{cccccc}
\hline & \multicolumn{2}{c}{ TNF $\alpha$ secreted } & & \multicolumn{2}{c}{ MCP-1 secreted } \\
\cline { 2 - 3 } \cline { 5 - 6 } Individual & Epithelial cells & IEL & & Epithelial cells & IEL \\
\hline & \multicolumn{2}{c}{$p g / m l$} & & & \multicolumn{2}{c}{$n g / m l$} \\
& 18.5 & 1.7 & & 2.8 & 0.1 \\
2 & 161.7 & 46.5 & & 2.2 & 0.2 \\
2 & 7.8 & 7.5 & & $2.4^{\ddagger}$ & 4.1 \\
3 & 4.7 & ND* & & 1.4 & ND \\
4 & 6.8 & ND & 1.0 & ND \\
5 & 7.7 & ND & & 0.7 & ND \\
6 & 11.2 & ND & 0.2 & ND \\
7 & & & &
\end{tabular}

* ND, not done. ${ }^{\ddagger}$ IEL and epithelial cells were cultured for $48 \mathrm{~h}$ at $2 \times 10 \% \mathrm{ml}$. Since IEL contamination of epithelial cell preparations was 2 to $3 \%, \sim 0.1 \mathrm{ng} / \mathrm{ml}$ of MCP-1 in the epithelial cell preparation of this patient likely derived from IEL contamination.

\section{Discussion}

A specific array of four proinflammatory cytokines, IL-8, MCP1 , TNF $\alpha$, and GM-CSF, was coordinately expressed and upregulated in human colon epithelial cell lines in response to bacterial invasion or stimulation with TNF $\alpha$ or IL-1. The regulated expression of this constellation of cytokines in human colon epithelial cells is noteworthy as each of these cytokines has an established role in the initiation and amplification of the inflammatory response. IL- 8 and MCP-1 are prototypic members of the C-X-C and C-C families of chemokines, and act as potent chemoattractants and activators of neutrophils and monocytes, respectively (38). TNF $\alpha$ can amplify the inflammatory response by activating neutrophils, mononuclear phagocytes, and other cell types such as eosinophils, whereas GM-CSF prolongs the survival of neutrophils, monocytes and eosinophils, and increases the response of those cells to other proinflammatory agonists which can further amplify the inflammatory response (39-42). In addition, TNF $\alpha$ can stimulate IL-8 and MCP- 1 production and GM-CSF can stimulate TNF $\alpha$ and IL-1 production by monocytes/macrophages $(39,41)$. The regulated expression of a specific array of proinflammatory cytokines in colon epithelial cell lines, as reported herein, suggests that these cells are programmed to provide chemotactic and activating signals to adjacent and underlying immune and inflammatory cells in the initial period following microbial invasion of epithelial cells. Further, production of proinflammatory cytokines by epithelial cells in response to TNF $\alpha$ or IL-1 produced by other cells in the epithelial microenvironment would serve to amplify the mucosal inflammatory response.

The characteristic array of proinflammatory cytokines produced by colon epithelial cell lines overlaps, but also exhibits some important differences from that produced by cells of the monocyte/macrophage lineage. Thus, none of the epithelial cells expressed IL-12p40 or high levels of IL-1, cytokines that are characteristic of the monocyte/macrophage lineage (43$45)$. Consistent with our findings, prior studies using Northern blot analysis also failed to detect IL-1 expression by freshly isolated human colon epithelial cells (46). The array of cytokines expressed by epithelial cells differs markedly from that 


\begin{tabular}{|c|c|c|c|c|c|c|}
\hline \multirow[b]{3}{*}{ Experiment/Additions to culture } & \multicolumn{6}{|c|}{ Cytokines secreted } \\
\hline & \multicolumn{2}{|c|}{ MCP-1 } & \multicolumn{2}{|c|}{ IL-8 } & \multicolumn{2}{|c|}{ IL-6 } \\
\hline & $\mathrm{pg} / \mathrm{ml}$ & $\begin{array}{l}\text { Fold increase } \\
\text { over controls }\end{array}$ & $\mathrm{pg} / \mathrm{ml}$ & $\begin{array}{l}\text { Fold increase } \\
\text { over controls }\end{array}$ & $\mathrm{pg} / \mathrm{ml}$ & $\begin{array}{l}\text { Fold increase } \\
\text { over controls }\end{array}$ \\
\hline \multicolumn{7}{|l|}{1} \\
\hline Y. enterocolitica & 278 & 4.5 & 1,248 & 3.1 & 514 & 6.0 \\
\hline L. monocytogenes & 182 & 2.9 & 953 & 2.3 & 493 & 5.7 \\
\hline E. coli $\mathrm{DH} 5 \alpha$ & 99 & 1.6 & 783 & 1.9 & 230 & 2.7 \\
\hline LPS & 94 & 1.5 & 669 & 1.6 & 154 & 1.8 \\
\hline IL-1 $\beta$ & 103 & 1.7 & 843 & 2.1 & 205 & 2.4 \\
\hline None & 62 & 1.0 & 408 & 1.0 & 86 & 1.0 \\
\hline \multicolumn{7}{|l|}{2} \\
\hline Y. enterocolitica & 551 & 1.8 & 2,953 & 1.2 & 1,652 & 2.3 \\
\hline E. coli DH5 $\alpha$ & 326 & 1.0 & 2,877 & 1.1 & 1,248 & 1.8 \\
\hline IL-1 $\beta$ & 619 & 2.0 & 5,689 & 2.2 & 1,673 & 2.3 \\
\hline None & 315 & 1.0 & 2,546 & 1.0 & 715 & 1.0 \\
\hline
\end{tabular}

* Intestinal epithelial cells were isolated from surgically resected colon specimens, infected for $1 \mathrm{~h}$ with different bacterial strains, and further incubated for 6-7 h in the presence of gentamicin. Parallel cultures were stimulated with $1 \mu \mathrm{g} / \mathrm{ml} \mathrm{IL-1 \beta}$ or $10 \mu / \mathrm{ml}$ LPS for 6-7 h. Cytokine concentrations in the supernatants were determined by ELISA. Numbers are means of two separate determinations.

characteristic of the $\mathrm{T}$ cell lineage. Thus, none of the epithelial cell lines expressed mRNA for IL-2, IL-4, IL-5, and IFN- $\gamma$, cytokines which are produced by $\mathrm{T}$ cells, but also variably by other cell types (e.g., mast cells, eosinophils and NK cells) (47-50). Taken together, our findings support the notion that epithelial cells are an integral component of the host's nonspecific (i.e., natural) immune system. This concept complements the finding of others that intestinal epithelial cells can be induced to express HLA class II molecules, can process and present antigen to $\mathrm{T}$ cells, and can express complement proteins (1-3, 11).

The colonic cell lines used in these studies are transformed and, in this regard, differ from normal colon epithelial cells. We note, however, that despite their different origins, an identical array of proinflammatory cytokine mRNAs was consistently upregulated in each of the cell lines in response to bacterial invasion and TNF $\alpha$ or IL-1 stimulation, suggesting that expression of these cytokines is a general property of colon epithelial cells. Moreover, our results argue that unless the expression or lack of expression of one or more of the cytokines is causally related to the transformation process, a similar array of cytokines should be produced by non-transformed colon epithelial cells. This was the case for TNF $\alpha$ and MCP-1 as shown herein, and for IL-8 (7) and GM-CSF (37), as we noted before. However, in contrast to those cytokines, IL- 6 was produced by freshly isolated normal colon epithelial cells but not by the colon epithelial cell lines studied herein and by others $(7,51)$. Consistent with our findings with freshly isolated cells, others have reported IL- 6 expression in normal human colon epithelial cells by immunostaining of tissue sections (9). However, in those studies, $<5 \%$ of the colon epithelial cells expressed that cytokine (9). Thus, the lack of IL-6 expression by the cell lines may reflect the origin of these cells from precursors which themselves did not express IL-6, rather than a loss of IL-6 expression in the cell lines related to the transformed state.

Cell lines will continue to provide useful models for charac- terizing the regulation of cytokine gene expression in colon epithelial cells. This is particularly the case given the heterogeneity and lack of purity of epithelial cell preparations obtained from fresh colonic tissue, the limited viability of these cells, and the current lack of long term lines of nontransformed human colon epithelial cells. This is further supported by our studies using freshly isolated colon epithelial cells. Although these cells, like the cell lines, can secrete proinflammatory cytokines like IL-8 or MCP-1, as well as IL-6, in response to bacterial invasion or stimulation with IL-1 $\beta$, they do not provide a useful model system for studying cytokine expression since background levels vary markedly from preparation to preparation, which may reflect the multiple manipulations performed in the isolation procedure. This parallels our findings showing that simple mechanical irritation of the colon mucosa can upregulate IL-8 mRNA expression (Y. Chowers and M. F. Kagnoff, unpublished data), and that of others showing that hypoxia induces IL-8 secretion in endothelial cells (52). In studies parallel to those with freshly isolated epithelial cells, we found freshly isolated monocytes also expressed high background levels of MCP-1 and IL-8. These cytokines were minimally increased by further stimulation with IL-1, PMA, or LPS (L. Eckmann, unpublished data). However, after several days in culture, baseline levels decreased and regulated expression in response to those agonists was seen. It is not possible to use a similar experimental approach with freshly isolated colon epithelial cells given their limited viability beyond $24-48 \mathrm{~h}$.

Invasion of the intestinal mucosa by pathogenic bacteria leads to a marked acute mucosal inflammatory response which is characterized histologically by an infiltration with neutrophils and macrophages/monocytes. Therefore, we used bacterial invasion, as a physiologically relevant model, to study the upregulation of proinflammatory cytokine expression in colon epithelial cells. As shown in these studies, bacterial invasion of the colon epithelial cell lines upregulated mRNA levels and secretion of IL-8, MCP-1, TNF $\alpha$, and GM-CSF, and could upregulate 
MCP-1, IL-8, and IL-6 secretion in freshly isolated epithelial cells. We suggest that these proinflammatory cytokines, in combination, comprise an important signaling system for the initiation of the mucosal inflammatory response when the host intestinal epithelial surface lining is invaded by microbial pathogens. Indeed, the specific array of proinflammatory cytokines expressed by epithelial cells is ideally suited for that function since, in combination, these cytokines attract and activate neutrophils and monocytes/macrophages, key cell types of the inflammatory response. Noninvasive bacterial strains and G. lamblia trophozoites do not invade intestinal epithelial cells or cause intestinal inflammation in vivo. The finding that they did not upregulate cytokine gene expression further highlights the importance of microbial entry for the activation of this cytokine signaling network. Our findings do not exclude the possibility that additional cytokines, including other members of the chemokine family, also may be part of this signaling network.

Levels of TNF $\alpha$ mRNA and TNF $\alpha$ secretion by T84 cells were upregulated in response to stimulation with TNF $\alpha$ or Salmonella infection. This suggests that TNF $\alpha$ produced by these cells may exhibit autocrine and paracrine effects. Thus, TNF $\alpha$ produced by epithelial cells in response to bacterial invasion or in response to stimulation with $\mathrm{TNF} \alpha$ could amplify its own expression and the inflammatory response by secondarily upregulating epithelial cell production of the additional proinflammatory cytokines IL-8, MCP-1, and GM-CSF. However, in contrast to T84, HT29, and SW620, freshly isolated colon epithelial cells and Caco- 2 cells did not respond to TNF $\alpha$ stimulation with increased proinflammatory cytokine expression (data not shown). This lack of TNF $\alpha$ responsiveness is consistent with the apparent lack of TNF $\alpha$ receptor expression on freshly isolated intestinal epithelial cells (53), although it is not yet clear whether or not functional TNF $\alpha$ receptors are expressed and regulated in colon epithelial cells in vivo.

In contrast to the proinflammatory cytokines, mRNA levels and secretion of TGF $\beta 1$, a cytokine which can exhibit potent immunosuppressive and anti-inflammatory activities $(26,27)$, were not upregulated in colon epithelial cells in response to TNF $\alpha$ stimulation or Salmonella invasion. Although TGF $\beta 1$ expression was reported to be increased in a rat small intestinal epithelial cell line (i.e., IEC-6) after IL-2 stimulation (36), this was not the case for the cell lines studied herein. It is possible that anti-inflammatory cytokines like TGF $\beta 1$ and IL-10 (28) can be regulated in human intestinal epithelial cells in response to different stimuli or, alternatively, epithelial cells may not play a major role in downregulation of the acute inflammatory response through the production of those cytokines. Irrespective of the cellular origin of the anti-inflammatory cytokines, the development of marked intestinal inflammation in transgenic IL-10 knockout mice demonstrates the importance of maintaining an appropriate balance in the intestinal mucosa between cytokines with proinflammatory and those with anti-inflammatory activities (54).

\section{Acknowledgments}

We thank Ms. Sharon Okamoto for expert technical assistance, and Ms. Debbie Lundemo for preparation of the manuscript.

This work was supported by National Institutes of Health grants DK-35108, DK-47739 and DK-40582, and grants from the Universitywide AIDS Research Program, the Pediatric AIDS Foundation and the Veterans Affairs Medical Research Service. L. Eckmann is a re- search fellow of the Crohn's and Colitis Foundation of America. E. Morzycka-Wroblewska was supported in part by a Junior Faculty Award from the American Cancer Society.

\section{References}

1. Mayer, L., and R. Shlien. 1987. Evidence for function of Ia molecules on gut epithelial cells in man. J. Exp. Med. 166:1471-1483.

2. Selby, W. S., G. Janossy, D. Y. Mason, and D. P. Jewell. 1983. Expression of HLA-DR antigens by colonic epithelium in inflammatory bowel disease. Clin. Exp. Immunol. 53:614-618.

3. Mayer, L., D. Eisenhardt, P. Salomon, W. Bauer, R. Plous, and L. Piccinini. 1991. Expression of class II molecules on intestinal epithelial cells in humans. Differences between normal and inflammatory bowel disease. Gastroenterology. 100:3-12.

4. Kaiserlian, D., D. Rigal, J. Abello, and J. P. Revillard. 1991. Expression, function and regulation of the intercellular adhesion molecule-1 (ICAM-1) on human intestinal epithelial cell lines. Eur. J. Immunol. 21:2415-2421.

5. Kvale, D., P. Krajci, and P. Brandtzaeg. 1992. Expression and regulation of adhesion molecules ICAM-1 (CD54) and LFA-3 (CD58) in human intestinal epithelial cell lines. Scand. J. Immunol. 35:669-676.

6. Kelly, C. P., J. C. O'Keane, J. Orellana, P. C. Schroy, S. Yang, J. T. LaMont, and H. R. Brady. 1992. Human colon cancer cells express ICAM-1 in vivo and support LFA-1-dependent lymphocyte adhesion in vitro. Am. J. Physiol. 263:G864-G870.

7. Eckmann, L., H.-C. Jung, C.-C. Schuerer-Maly, A. Panja, E. MorzyckaWroblewska, and M. F. Kagnoff. 1993. Differential cytokine expression by human intestinal epithelial cell lines: regulated expression of interleukin-8. Gastroenterology. 105:1689-1697.

8. McCormick, B. A., S. P. Colgan, C. Delp-Archer, S. I. Miller, and J. L. Madara. 1993. Salmonella typhimurium attachment to human intestinal epithelial monolayers: Transcellular signalling to subepithelial neutrophils. J. Cell Biol. 123:895-907.

9. Shirota, K., L. LeDuy, S. Yuan, and S. Jothy. 1990. Interleukin-6 and its receptor are expressed in human intestinal epithelial cells. Virchows Arch. B Cell Pathol. 58:303-308.

10. Anzano, M. A., D. Rieman, W. Prichett, D. F. Bowen-Pope, and R. Greig 1989. Growth factor production by human colon carcinoma cell lines. Cancer Res. 49:2898-2904.

11. Andoh, A., Y. Fujiyama, T. Bamba, and S. Hosoda. 1993. Differential cytokine regulation of complement $\mathrm{C} 3, \mathrm{C} 4$, and factor B synthesis in human intestinal epithelial cell line, Caco-2. J. Immunol. 151:4239-4247.

12. Dias, V. C., J. L. Wallace, and H. G. Parsons. 1992. Modulation of cellular phospholipid fatty acids and leukotriene B4 synthesis in the human intestinal cell (CaCo-2). Gut. 33:622-627.

13. Phillips, J. O., M. P. Everson, Z. Moldoveanu, C. Lue, and J. Mestecky. 1990. Synergistic effect of IL-4 and IFN-gamma on the expression of polymeric Ig receptor (secretory component) and IgA binding by human epithelial cells. $J$. Immunol. 145:1740-1744.

14. Mulder, K. M., Q. Zhong, H. G. Choi, L. E. Humphrey, and M. G. Brattain 1990. Inhibitory effects of transforming growth factor beta 1 on mitogenic response, transforming growth factor alpha, and c-myc in quiescent, well-differentiated colon carcinoma cells. Cancer Res. 50:7581-7586.

15. Fantini, J., C. Bolmont, and N. Yahi. 1992. Tumor necrosis factor-alpha stimulates both apical and basal production of HIV in polarized human intestinal HT29 cells. Immunol. Let. 34:85-90.

16. Ullmann, C. D., J. Schlom, and J. W. Greiner. 1992. Interleukin-6 increases carcinoembryonic antigen and histocompatibility leukocyte antigen expression on the surface of human colorectal carcinoma cells. J. Immunother. 12:231-241.

17. Das, K. M., L. Squillante, and F. M. Robertson. 1993. Amplified expression of intercellular adhesion molecule-1 (ICAM-1) and $M(r) 40 \mathrm{~K}$ protein by DLD-1 colon tumor cells by interferon-gamma. Cell. Immunol. 147:215-221.

18. Raitano, A. B., and M. Korc. 1993. Growth inhibition of a human colorectal carcinoma cell line by interleukin 1 is associated with enhanced expression of gamma-interferon receptors. Cancer Res. 53:636-640.

19. Mosmann, T. R., and R. L. Coffman. 1989. TH1 and TH2 cells: different patterns of lymphokine secretion lead to different functional properties. Annu. Rev. Immunol. 7:145-173.

20. Wierenga, E. A., M. Snoek, H. M. Jansen, J. D. Bos, R. A. van Lier, and M. L. Kapsenberg. 1991. Human atopen-specific types 1 and $2 \mathrm{~T}$ helper cell clones. J. Immunol. 147:2942-2949.

21. Del Prete, G. F., M. De Carli, C. Mastromauro, R. Biagiotti, D. Macchia P. Falagiani, M. Ricci, and S. Romagnani. 1991. Purified protein derivative of Mycobacterium tuberculosis and excretory-secretory antigen(s) of Toxocara canis expand in vitro human $\mathrm{T}$ cells with stable and opposite (type $1 \mathrm{~T}$ helper or type $2 \mathrm{~T}$ helper) profile of cytokine production. J. Clin. Invest. 88:346-350.

22. Mahanty, S., C. L. King, V. Kumaraswami, J. Regunathan, A. Maya, K. Jayaraman, J. S. Abrams, E. A. Ottesen, and T. B. Nutman. 1993. IL-4- and 
IL-5-secreting lymphocyte populations are preferentially stimulated by parasitederived antigens in human tissue invasive nematode infections. J. Immunol. 151:3704-3711.

23. Yamamura, M., K. Uyemura, R. J. Deans, K. Weinberg, T. H. Rea, B. R. Bloom, and R. L. Modlin. 1991. Defining protective responses to pathogens: cytokine profiles in leprosy lesions. Science (Wash. DC). 254:277-279.

24. Yamamura, M., X. H. Wang, J. D. Ohmen, K. Uyemura, T. H. Rea, B. R. Bloom, and R. L. Modlin. 1992. Cytokine patterns of immunologically mediated tissue damage. J. Immunol. 149:1470-1475.

25. Pirmez, C., M. Yamamura, K. Uyemura, M. Paes-Oliveira, F. ConceicaoSilva, and R. L. Modlin. 1993. Cytokine patterns in the pathogenesis of human leishmaniasis. J. Clin. Invest. 91:1390-1395.

26. Shull, M. M., I. Ormsby, A. B. Kier, S. Pawlowski, R. J. Diebold, M. Yin, R. Allen, C. Sidman, G. Proetzel, and D. Calvin. 1992. Targeted disruption of the mouse transforming growth factor-beta 1 gene results in multifocal inflammatory disease. Nature (Lond.). 359:693-699.

27. Wahl, S. M. 1992. Transforming growth factor beta (TGF-beta) in inflammation: a cause and a cure. J. Clin. Immunol. 12:61-74.

28. Cassatella, M. A., L. Meda, S. Bonora, M. Ceska, and G. Constantin 1993. Interleukin 10 (IL-10) inhibits the release of proinflammatory cytokines from human polymorphonuclear leukocytes. Evidence for an autocrine role of tumor necrosis factor and IL-1 beta in mediating the production of IL-8 triggered by lipopolysaccharide. J. Exp. Med. 178:2207-2211.

29. Standiford, T. J., S. L. Kunkel, M. A. Basha, S. W. Chensue, J. P. Lynch, G. B. Toews, J. Westwick, and R. M. Strieter. 1990. Interleukin-8 gene expression by a pulmonary epithelial cell line. A model for cytokine networks in the lung. J. Clin. Invest. 86:1945-1953.

30. Wang, A. M., M. V. Doyle, and D. F. Mark. 1989. Quantitation of mRNA by the polymerase chain reaction. Proc. Natl. Acad. Sci. USA. 86:9717-9721.

31. Chikami, G. K., J. Fierer, and D. G. Guiney. 1985. Plasmid-mediated virulence in Salmonella dublin demonstrated by use of a Tn5-oriT construct. Infect. Immun. 50:420-424.

32. Gillin, F. D., D. S. Reiner, and S. E. Boucher. 1988. Small-intestinal factors promote encystation of Giardia lamblia in vitro. Infect. Immun. 56:705707.

33. Eckmann, L., M. F. Kagnoff, and J. Fierer. 1993. Epithelial cells secrete the chemokine interleukin-8 in response to bacterial entry. Infect. Immun. 61:4569-4574.

34. McRoberts, J. A., and K. E. Barrett. 1989. Hormone-regulated ion transport in T84 colonic cells. In Functional epithelial cells in culture. K. S. Matlin and J. D. Valentich, editors. Alan R. Liss, New York. 235-265.

35. Kekow, J., W. Wachsman, J. A. McCutchan, W. L. Gross, M. Zachariah, D. A. Carson, and M. Lotz. 1991. Transforming growth factor $\beta$ and suppression of humoral immune responses in HIV infection. J. Clin. Invest. 87:1010-1016.

36. Ciacci, C., Y. R. Mahida, A. Dignass, M. Koizumi, and D. K. Podolsky. 1993. Functional interleukin-2 receptors on intestinal epithelial cells. J. Clin. Invest. 92:527-532.

37. Panja, A., L. Eckmann, M. F. Kagnoff, and L. Mayer. 1994. Increased production of IL-8 and GM-CSF by intestinal epithelial cells in inflammatory bowel disease. Gastroenterology. 106:A750.

38. Oppenheim, J. J., C. O. Zachariae, N. Mukaida, and K. Matsushima. 1991
Properties of the novel proinflammatory supergene "intercrine" cytokine family. Annu. Rev. Immunol. 9:617-648.

39. Danis, V. A., G. M. Franic, D. A. Rathjen, and P. M. Brooks. 1991. Effects of granulocyte-macrophage colony-stimulating factor (GM-CSF), IL-2, interferon-gamma (IFN- $\gamma$ ), tumour necrosis factor-alpha (TNF-alpha) and IL-6 on the production of immunoreactive IL-1 and TNF-alpha by human monocytes. Clin. Exp. Immunol. 85:143-150.

40. DeNichilo, M. O., A. G. Stewart, M. A. Vadas, and A. F. Lopez. 1991 Granulocyte-macrophage colony-stimulating factor is a stimulant of platelet-activating factor and superoxide anion generation by human neutrophils. J. Biol. Chem. 266:4896-4902.

41. Ferrante, A. 1992. Activation of neutrophils by interleukins-1 and -2 and tumor necrosis factors. Immunol. Ser. 57:417-436.

42. Lopez, A. F., M. J. Elliott, J. Woodcock, and M. A. Vadas. 1992. GM CSF, IL-3 and IL-5: cross-competition on human haemopoietic cells. Immunol. Today. 13:495-500.

43. Dinarello, C. A. 1991. Interleukin-1 and interleukin-1 antagonism. Blood. 77:1627-1652

44. D’Andrea, A., M. Rengaraju, N. M. Valiante, J. Chehimi, M. Kubin, M. Aste, S. H. Chan, M. Kobayashi, D. Young, and E. Nickbarg. 1992. Production of natural killer cell stimulatory factor (interleukin 12) by peripheral blood mononuclear cells. J. Exp. Med. 176:1387-1398.

45. Trinchieri, G. 1993. Interleukin-12 and its role in the generation of TH1 cells. Immunol. Today. 14:335-338.

46. Youngman, K. R., P. L. Simon, G. A. West, F. Cominelli, D. Rachmilewitz, J. S. Klein, and C. Fiocchi. 1993. Localization of intestinal interleukin 1 activity and protein and gene expression to lamina propria cells. Gastroenterology. 104:749-758.

47. Lorenzen, J., C. E. Lewis, D. McCraken, E. Horak, M. Greenall, and J. O. McGee. 1991. Human tumour-associated NK cells secrete increased amounts of interferon-gamma and interleukin-4. Br. J. Cancer. 64:457-462.

48. Bradding, P., I. H. Feather, S. Wilson, P. G. Bardin, C. H. Heusser, S. T Holgate, and P. H. Howarth. 1993. Immunolocalization of cytokines in the nasal mucosa of normal and perennial rhinitic subjects. The mast cell as a source o IL-4, IL-5, and IL-6 in human allergic mucosal inflammation. J. Immunol. 151:3853-3865.

49. Galli, S. J., J. R. Gordon, and B. K. Wershil. 1993. Mast cell cytokines in allergy and inflammation. Agents Actions. 43:209-220.

50. Desreumaux, P., A. Janin, J. F. Colombel, L. Prin, J. Plumas, D. Emilie G. Torpier, A. Capron, and M. Capron. 1992. Interleukin 5 messenger RNA expression by eosinophils in the intestinal mucosa of patients with coeliac disease. J. Exp. Med. 175:293-296.

51. Hedges, S., M. Svensson, and C. Svanborg. 1992. Interleukin-6 response of epithelial cell lines to bacterial stimulation in vitro. Infect. Immun. 60:12951301.

52. Karakurum, M., R. Shreeniwas, J. Chen, D. Pinsky, S. D. Yan, M. Anderson, K. Sunouchi, J. Major, T. Hamilton, K. Kuwabara, A. Rot, R. Nowygrod, and D. Stern. 1994. Hypoxic induction of interleukin-8 gene expression in human endothelial cells. J. Clin. Invest. 93:1564-1570.

53. Panja, A., S. Goldberg, and L. Mayer. 1993. Expression and regulation of cytokine receptors on intestinal epithelial cells from normal controls and patients with IBD. Gastroenterology. 104:A759.

54. Kühn, R., J. Löhler, D. Rennick, K. Rajewsky, and W. Muller. 1993 Interleukin-10-deficient mice develop chronic enterocolitis. Cell. 75:263-274. 